\title{
UNA PUESTA AL DÍA DE LA TEORÍA AUTOFICTICIA COMO CONTRATO DE LECTURA AUTOBIOGRÁFICA
}

\author{
Francisco Ernesto PUERTAS MOYA
}

SELITEN@T / Universidad de La Rioja

\begin{abstract}
Resumen: La autoficción, una mezcla de realidad autobiográfica, metáforas y fragmentos inventados, ha descubierto la ficcionalidad del yo autobiográfico. Actualmente se constata la expansión de la autobiografía hasta las fronteras de la ficción en novelas que utilizan la primera persona gramatical y en las que la identidad nominal se suplanta con fórmulas que forman parte de la ficcionalidad del yo.
\end{abstract}

Résumé: L'autofiction, mélange de réalité autobiographique, de métaphores et de fragments inventés, a decouvert la fictionalité du je autobiographique. On constate actuellement l'expansion de l'autobiographie jusqu'aux frontières de la fiction dans les romans qui utilisent la première personne gramaticale, dont l'idéntité nominale peut être supplantée par des formules extra-textuelles qui font partie de la fictionalité du je autobiographique.

Palabras clave: autoficción, contrato de lectura, ficcionalidad, autobiografía

Mots clé: Autofiction, contrat de lecture, fictionalité, autobiographie. 


\section{DEFINICIÓN DEL TÉRMINO AUTOFICCIÓN}

La expansión del fenómeno autobiográfico ha llegado a invadir el terreno de la ficción, dando lugar a esas formas peculiares de novelas autobiográficas que, o bien recurren al inveterado uso de la primera persona, o bien revelan a través de la identidad nominal entre autor y protagonista la referencialidad del texto con respecto a la vida del escritor responsable de la obra. La casuística en el terreno de la ficción autobiográfica es inmensa, al ponerse en relación dos ámbitos tan extensos como el de lo ficticio y lo autobiográfico, con constantes innovaciones técnicas que se nutren de las dos realidades matrices, por lo que nos encontramos ante un campo de estudio al que sólo muy recientemente se ha prestado atención teórica. En relación con el término autoficción, seguimos la reciente tradición española que ha aceptado traducir la denominación francesa, autofiction, aunque Manuel Alberca (1999: 55) reconocía que "hubiera sido más acertado traducir por autonovela".

Para hacernos una idea de los problemas que suscita el acceso a este ámbito narrativo híbrido entre la ficción novelesca y la incomprobable realidad autobiográfica, no tenemos más que observar que en la década de 1970 Serge Doubrovski acuñó el término (autofiction) para referirse a esta modalidad, que Philippe Lejeune no contemplaba como factible en el campo de los subgéneros autobiográficos, al no coincidir el nombre de autor y protagonista, base sustentadora del pacto autobiográfico, o por considerar irreales los sucesos que se narraban, incumpliéndose así el requisito de veracidad que se presupone en el género autobiográfico. Aunque hoy el término autoficción está aceptado o normalizado (con las lógicas reticencias, como veremos), no hay que olvidar que su origen proviene de una práctica novelística más que de un marco teórico.

Ahora bien, no creemos que la práctica autoficticia sea tan novedosa, cuando podríamos remontarnos a períodos de la historia literaria en que no existía el género autobiográfico propiamente dicho, por lo que hay obras que podríamos incluir entre las manifestaciones pre-autoficticias si consideramos lo que sostienen Giné y SalaValldaura (1998: 9) sobre "la ficció disimulada com a autobiografia del Libro de buen amor, de Juan Ruiz”. En España, además, la tradición cultural de la novela de pícaros supone un motivo más para la reconsideración de la antigüedad y vigencia de esta modalidad. 


\section{SUBGÉNERO HÍBRIDO}

Desde una pespectiva que permite juzgar los acontecimientos en su desarrollo más continuado, parece oportuno considerar que el yo, que ideológicamente está formándose a la par que la burguesía se consolida como clase dominante y que convierte el individualismo en uno de sus baluartes más afianzados, ese mismo yo que titubea y duda entre la realidad autobiográfica y la ficción novelesca, empapa todas las manifestaciones artísticas desde el Renacimiento hasta nuestros días, en los que la transformación social e ideológica de la burguesía, en un mundo globalizado, exige de otras formas de expresión que se habían venido reclamando y experimentando desde las postrimerías del siglo XIX y primeras décadas del XX, en un preludio de lo que llegaría a ser la Post-modernidad. Así se entiende que ese mismo yo que conformó la novela burguesa, desde sus orígenes renacentistas hasta el Realismo y el Naturalismo decimonónicos, siga vigente y actuante, aunque larvado y escondido en su propia irrealidad, en la novela post-clásica, de la que Gonzalo Navajas (1987: 10) ha afirmado:

Centrada más en el yo como entidad autosuficiente que como integrante de un grupo supraindividual, ha utilizado diversas variantes de la confesión (el monólogo interior, el flujo de la conciencia, etc.) en las que la revelación de las zonas más profundas del yo se convierten en la motivación primordial del texto.

Sin ese permanente intercambio de técnicas, valores, aspiraciones y criterios que se ha venido realizando entre novela y autobiografía, la Modernidad carecería del nexo principal que la articula, el yo del que se sigue nutriendo la rebeldía de una clase como la burguesa que, desde una interpretación marxista de la Historia (hoy ni siquiera cotizada en la bolsa de las ideas, pero que ha estado vigente durante más de un siglo), ha generado sus propias contradicciones de clase, la primera y principal de cuyas contradicciones, la más irresoluble por más absoluta, sin ninguna duda es el yo proteico que se observa latente como el motor que ha incentivado el desarrollo de la sociedad y de la estética en los últimos cinco siglos.

La utilización de la primera persona en la novela popular urbana es un buen indicativo de esa interacción que comenzará a producirse entre literatura y vida, entre ficción y realidad, que tendrá como nexo de enlace la potente voz de la subjetividad que se constituye en el Renacimiento y se afianza a partir del siglo XVIII y del 
Romanticismo, aunque la crítica literaria no haya formulado sus teorías sobre este resbaladizo campo de frontera entre la novela y la autobiografía hasta hace pocos años. De hecho, la primera, y única hasta el momento, definición que se ha popularizado sobre la autoficción se debe al francés Lecarme, cuya formulación es la siguiente:

L'autofiction est d'abord un dispositif très simple: soit un récit dont auteur, narrateur et protagoniste partagent la même identité nominale et dont l'intitulé générique indique qu'il s'agit d'un roman (apud. Alberca, 1996a: 10).

En el propio término se hace mención a esta dualidad, por la cual el texto resultante ocupa una posición imprecisa e inestable, puesto que se trata de una narración ficticia en la que el autor escribe sobre sí mismo, aunque utilice para ello a un personaje al que le presta su propio nombre u otros mecanismos de identificación.

El espacio que ocupa la autobiografía novelada, o autonovela, denominaciones que también pueden emplearse para referirse a este tipo de obras, es siempre fronterizo, inestable, a medio camino entre dos realidades, indeciso y difuso. Quienes han aprovechado la experiencia cultural proporcionada por la práctica común de escritura de diarios, memorias, autobiografías, epistolarios, etc. han sido los novelistas, que han incorporado al acervo de sus creaciones la modalidad autobiográfica. Esto nos obliga a preguntarnos de qué manera y hasta qué punto hay una ósmosis o intercambio de estilos, que suelen ser evidentes en el caso de los textos ficticios que adoptan alguno(s) de los rasgos que caracterizan la literatura autobiográfica, pero que están menos estudiados en el caso de las técnicas y recursos novelísticos o puramente literarios empleados por la literatura intimista, que a simple vista es más espontánea y directa, tópico éste ampliamente difundido por quienes no conocen el grado de elaboración artística que requiere un texto autobiográfico.

Esta situación de influencia mutua se hace cada vez más evidente, porque se ha producido una ruptura consciente, por parte de los artistas, de los planos reales y ficticios en el seno de las producciones estéticas, lo que ha permitido a la novela adentrarse en el territorio de la vida, del mismo modo que la autobiografía, al aspirar a su condición de género literario, ha apostado por su estetización, por su presentación bajo moldes y postulados que inciden en la elaboración artística. 
También existe una explicación social, o histórica, que avala esa atención cada vez mayor que se presta al individuo en los últimos años: el derrumbe de los grandes sistemas ideológicos que acreditaban lo colectivo frente a lo individual (Molero, 2000: 67), devolviendo al primer plano de la argumentación literaria al individuo común, vulgar, que acapara todos los intereses por explicarlo y comprenderlo. El auge experimentado por la autoficción responde no sólo a esta re-individualización que coincide con el apogeo del sistema liberal como pensamiento único (político, económico, ideológico) que se propugna como factible en exclusiva, sino también a motivaciones estéticas, que tienen que ver con el rutinario encasillamiento en que las modalidades autobiográficas habían caído, siendo previsibles y tópicos sus resultados en muchas ocasiones, lo que obligaba a romper moldes y esquemas, empezando por esa transgresión de los márgenes de la ficción, de modo que resultase imprescindible una duda metódica sobre la veracidad de lo relatado en un texto supuestamente autobiográfico por su cercanía con los modelos de narración novelesca.

De ahí que pueda postularse que el género autobiográfico fue depositando en la novela ciertas técnicas y recogiendo otras (Franzina, 1992: 122; Tortosa Garrigós, 2001: 37 ), en cuyo trasvase se provocó un espacio intermedio, fronterizo, que se afianzó como subgénero por la afinidad narrativa que caracteriza a la novela y a ciertas modalidades autobiográficas. En este sentido, Georges May (1982: 134) indicaba que la autobiografía (como modalidad) estaba orgánicamente más emparentada con la novela que con las memorias, tal vez por su carácter narrativo temporal, menos atento a lo anecdótico que a lo argumental. Ambas modalidades de escritura, de algún modo, no sólo comparten técnicas sino que sólo pueden ser distinguidas o separadas por la voluntad del lector y del autor a la hora de clasificarlas (Molino, 1991: 134).

Esta identificación formal entre novela y autobiografía facilita la creación de un subgénero híbrido, como el de la autoficción, en el que se alienta la duda sobre el carácter verídico o ficcional de lo relatado, puesto que se anula la distinción entre invención imaginativa y narración realista, a lo que se suma la inexistencia de marcas formales o rasgos pertinentes que permitan diferenciar intratextualmente un relato ficticio con forma autobiográfica de un relato verídico o no ficticio propiamente autobiográfico (Catelli, 1986: 67; Eakin, 1994: 12; Lejeune, 1994: 136); esta confusión que se crea entre textos autobiográficos y aquellos otros que utilizan sus recursos con fines estéticos no beneficia solamente a la nove la sino que ha abierto nuevas vías de 
expresión en las tendencias más actuales de lo autobiográfico que se han refugiado en la doblez de la ficción para intrigar más al lector en la interpretación sobre la veracidad de lo leído.

La existencia de precedentes autoficticios en la tradición novelesca española viene a mostrar la irresistible tentación que en todo momento han sentido los escritores por traspasar los límites de la ficción con la narración de hechos verídicos que los afectaban, aunque es probable que lo que se esconde en muchos modos de lectura realista no sea más que el deseo por reconocer la copia a que ha procedido el autor, desmintiendo así su falta de inspiración e inventiva. En este sentido, lo realmente novedoso que se produce en la autoficción es la voluntad consciente y (re)buscada de jugar con los planos e identidades de la personalidad autorial (Alberca, 1996a: 16), que instiga al lector a pronunciarse.

Haciéndose eco de la nueva actitud que estas corrientes autobiográficas han propiciado en el modo de lectura de los textos autobiográficos, ya en 1975, fecha de la primera redacción de sus tesis sobre el género, Philippe Lejeune avisaba sobre la paradójica actitud del lector que no sólo afecta a la autobiografía sino que llega incluso a repercutir en su modo de leer novelas, resaltando

la importancia del contrato en la medida en que determina la actitud del lector: si la identidad no es afirmada (caso de la ficción), el lector tratará de establecer parecidos a pesar del autor; si se la afirma (caso de la autobiografía), tenderá a encontrar diferencias (errores, deformaciones, etc.) (Lejeune, 1994: 65).

En todo caso, la novedad que reporta la autobiografía como género (y que se refleja en todas sus modalidades) es el replanteamiento de las relaciones extratextuales o de referencialidad, por lo que sólo fuera del texto podrá encontrarse la respuesta a la veracidad o falsedad de lo que se narra.

De este modo, hay una especie de intuición en el lector de novelas que busca en el texto ficticio aquellos datos que puedan pertenecer a la vida real del autor, hasta el punto de crear ciertas presunciones o presuposiciones que difícilmente pueden ser desarraigadas de la mente del lector, quien se dejará llevar por la creencia en el respeto a la verosimilitud que caracteriza a los hechos narrativos contenidos en una novela por el mero hecho de utilizar la primera persona. La búsqueda de esos datos extratextuales podrá realizarse, en algunas ocasiones, en los propios textos manifiestamente 
autobiográficos en los que el autor realiza las comparaciones oportunas. No basta con esta comprobación referencial o extratextual, dado que ello no siempre sucede, y en todo caso es una ratificación por otro texto literario al que se concede (por convención) el rango de verídico.

Lo llamativo en la autoficción es que el autor se trata a sí mismo como un personaje; su vida o un fragmento de ella se transforma en texto literario y él mismo se eleva a la categoría de protagonista, que doblegado por la voluntad del autor tendrá que repetir con leves modificaciones lo que ya tuvo que padecer y experimentar a causa del azar en la vida real. La autoficción se concibe así como un juego de espejos en el que la intención revisora del autor no está exenta de ironía y autocrítica. En la confusión de autor y protagonista hay una provocación estética no sólo al lector sino a los propios márgenes que se le habían concedido a la ficción tradicionalmente, permitiéndole que entre en la vida y la re-haga a voluntad. La confusión no sería tal si no hubiese lugar a las dudas y a las vacilaciones, por lo que para hablar de autoficción tendremos que presuponer cierta ambigüedad e indecisión a la hora de atribuir veracidad o superchería a los episodios que en el texto se reflejan, distorsionados o literalmente reproducidos. En esa sinuosa y equívoca posibilidad se encuentra el reto de aventurarse a seguir la trayectoria de un protagonista a medias inexistente y a medias real, cuya dualidad alterna siempre entre los difusos ámbitos de la realidad y la ficción, traspasando sus fronteras, dejándose traspasar por ellas, las confunde y altera en un juego que obliga a profundizar reflexivamente en las falaces estructuras de la realidad y en las sólidas bases culturales de la ficción, por no hablar de la inestable constitución del yo.

La base que sustenta esta posibilidad de confusión se encuentra, ya lo adelantábamos, en un dato extra-textual que vincula y pone en relación al autor y al personaje de su obra, el nombre propio o el pseudónimo que identifica a ambos y los hace semejantes por su aspecto físico y por datos externos (geográficos, históricos, sociales, profesionales, etc.) que hacen factible la asimilación del personaje con el autor, como pone de manifiesto el propio Alberca (1996b: 176).

¿Pueden ser consideradas estas referencias extra-textuales datos autobiográficos que se diseminan en la obra con el fin de hacerla más real? ¿O hemos de creer que se trata de invenciones que toman como punto de partida un entorno que el escritor conoce bien, como sucede al ambientar el relato en una ciudad conocida y no en un país en el que nunca se ha estado? Es lógico que el mundo ficcional al que pertenecen muchas 
novelas sea compartido con el ámbito autobiográfico, por lo que ambas mantienen diferencias en cuanto son productos estéticos. Para atribuir cualidad autobiográfica a una obra no basta, por tanto, con la referencialidad, sino también la finalidad pretendida.

La imaginación actúa sobre una base de recuerdos, por más que ello no confiere a toda obra memorial la condición de autobiográfica, pues ésta suma a la referencialidad la pretensión manifiesta del autor. La voluntad del escritor determina que una obra esté en el ámbito autobiográfico o no lo esté. El subgénero autoficticio supone una incursión en la autobiografía, manteniendo la vinculación con la confesionalidad y con la revelación de un secreto. Todo este debate sobre las intenciones de la autoría, la referencialidad textual y la interpretación por el modo de lectura nos llevará a preguntarnos sobre cuál es la realidad de la autoficción y qué posición ocupa en el canon de géneros. En un término intermedio entre la realidad y la ficción situaba Lejeune el estatus de la novela autobiográfica, puesto que en ella entrarían elementos de la realidad personal que sugieren un parecido con la vida del autor, pero no una igualdad o identificación como la pretendida por la obra autobiográfica. Por su parte, con el término autoficción aceptado, Manuel Alberca $(1996 \mathrm{a} ; 1999)$ ha señalado su ambigüedad esencial, motivo por el que prefiere referirse al pacto ambiguo que lo caracteriza, al estar a medio camino entre la realidad y la ficción. En un análisis pormenorizado de su procedencia dual, para Alberca (1999: 58) esta mixtura debería ser considerada "como un producto de ingeniería literaria, un híbrido elaborado a partir de elementos autobiográficos y novelescos". Esta idea es apropiada en tanto alude a la manipulación que se realiza en el laboratorio de la función estética sobre los recuerdos vitales, alterándose y concediéndoles una significación diferente a la que tuvieron como hechos reales. También Manuela Ledesma (1999: 13n) ha aludido a la naturaleza híbrida o dual que compartían las ficciones autobiográficas a las que se refería como

novelas que se leen como autobiografías y que lo parecen, es decir, una especie de híbrido que está a medio camino entre la autobiografía (en la que la identidad autor-narrador-personaje es un hecho) y la novela (en la que referencialidad de este tipo es mínima en beneficio de la ficción).

Para incidir en la idea de construcción artificial, en la que se programan y utilizan recursos procedentes de géneros diferenciados, Stone puso 306 en circulación a 
principios de la década de 1980 en el ámbito anglosajón ${ }^{1}$ la forma faction, procedente de la fusión de factual fiction.

Esta mezcla, realizada con realidades y deseos a partes iguales, con hechos verídicos e inventados, venía a abrir un nuevo campo de actuación en la autobiografía como género, aunque ambas ya poseían prestados valores del otro género. Por ello, es posible aceptar la existencia de autobiografías disimuladas bajo formas ficcionales mucho antes de que se constituyese el género autobiográfico, al encontrar en las ficciones novelescas algunos efectos de realidad que referían a un universo ficcional próximo al mundo real conocido y compartido por autor y lectores. Se ha producido, pues, un fenómeno novedoso que es la transgresión de fronteras, cuya finalidad concreta es provocar dudas e incertidumbres en el lector.

Estas prácticas intermedias o mezcladas no son sólo la autoficción y el poema autobiográfico, sino que están presentes en la configuración de toda la estela autobiográfica, cada vez más contaminada por otras experiencias estéticas, al tiempo que las contagia de su propia vitalidad. Pero esta intermediación supone, a su vez, la pertenencia de sus respectivos campos a un espacio común que en este caso sería el género autobiográfico.

En este amplio espacio autobiográfico, que acoge obras diversas y modalidades complejas, se van difuminando las barreras que encorsetaban los subgéneros y las expresiones dentro de unos moldes fijos. A su vez, como vienen demostrando muchas prácticas literarias desde Lazarillo de Tormes, Teresa de Cepeda o Diego Torres de Villarroel a nuestros días, la frontera que separa la vida de la ficción ha sido desplazada a consecuencia de la constitución de la literatura autobiográfica en género. Jugando con esa calculada ambigüedad, ciertos autores han contaminado de ficción su vida (para mitografiarse) y han colmado de hechos reales sus textos literarios, a fin de confundir a sus lectores y, posteriormente, a sus críticos y estudiosos, que se hallan divididos al atender a su vida o a las novelas para proceder a una interpretación de su pensamiento.

La raíz de esta confusión se encuentra en la imitación que el texto literario (la autoficción) hace de la vida referencial que está narrando, hasta adaptarla a unos modelos estéticos que responden a los gustos y preferencias de la sociedad en que dicha novela (como artefacto estético) se produce. Es importante, pues, no creer que se trata

1 "Les Américains utilisent le terme de surfiction, d'autres celui de fiction of fact ou de faction" (Lecarme y Lecarme-Tabone, 1999: 275). 
de una mera reproducción, sino que existe un tratamiento artístico, una mediación, que modula la propia vida al elegir también sus modelos de conducta y sus comportamientos públicos, sociales. Conviene subrayar que se pretende la similitud e identificación entre el autor y el protagonista, aunque en el caso de la autoficción (y ésta es una característica distintiva que la separa de la modalidad autobiográfica) la semejanza no ha de ser plena, porque el parecido o la similitud admiten grados de comparación, mayor o menor semejanza, pero la autobiografía propiamente dicha no puede ser graduada como más o menos verdadera, más o menos atenta y atenida a la realidad, como ha aseverado Philippe Lejeune (1994: 63).

Las gradaciones existen en la novela, donde se pueden inventar, fingir o crear más o menos elementos reales, donde la libertad de creación también permite introducir hechos, personajes, lugares de la realidad extratextual sin que esto cambie su estatus y carácter ficticio. No hay, no obstante, que olvidar el territorio común en que se desarrollan autoficciones y autobiografías. El motivo de esta continuidad lo encontramos en el carácter narrativo que sustenta a ambas, así como en la existencia de un tiempo y un espacio que se trasladan a la escritura conservando su nombre o transformándolo, como sucede en bastantes documentos autobiográficos que para ser publicados previamente se expurgan, despistando al lector con el cambio de nombres propios o su sustitución por iniciales o asteriscos. Este fenómeno, que no se descarta en los diarios, epistolarios y memorias, puede producirse en las autoficciones por el temor del autor a ser reconocido en la figura del protagonista en que vierte su propia personalidad. En el espacio autoficticio la ambigüedad con que se presenta la identidad protagonista-autor facilita la expresión de los sentimientos más profundos, porque la indefinición de la frontera entre real e imaginario sirve de refugio y amparo a la sinceridad encubierta.

Queda, pues, de manifiesto la radical ambigüedad de textos como los autoficticios que son el resultado de la mezcla de géneros, ya de por sí muy influidos por otras modalidades y técnicas expresivas, resaltando la idoneidad de la autoficción para una época de incertidumbres y sospechas, como la abierta por la Modernidad. Así es como la configuración de este subgénero híbrido, el autonovelesco, sirve para poner en duda el estatus en el que se asientan los géneros matrices de los que ha surgido, a saber, la novela y la autobiografía, géneros burgueses por antonomasia. 
Una vez que nos resignamos a no poder confirmar en todos sus extremos la veracidad de los episodios narrados en una obra autoficticia, ni siquiera a saber si ésta pertenece al ámbito de la ficción novelesca o a la creación autobiográfica, al menos conviene saber cómo distinguirla de las novelas, qué rastros y pistas va dejando el autor para que la reconozcamos e identifiquemos como tal. El dato más significativo suele ser la identidad nominal, aunque éste no siempre se revela de un modo directo, por lo que podemos encontrarnos con un protagonista anónimo, sin nombre, al que debamos identificar con el autor mediante otros sistemas que la mera atribución de idéntico nombre.

Como ha delimitado Alicia Molero (2000: 42-43), hay tres posibilidades (autoalusiva, paratextual e intertextual) de asignar a una novela su condición de autobiográfica:

1. Ficciones que contienen factores textuales de identificación, sea el nombre propio o autoalusiones de similar valor referencial.

2. Las que portan factores de identificación paratextual, mediante los cuales el autor ofrece al lector elementos de relación con el personaje a través de prólogos, reseñas, contraportadas, dedicatorias, presentaciones, aclaraciones, etc.

3. En otros casos la relación se debe al factor intertextual, posible únicamente cuando el lector cuenta con otros textos-testigo como entrevistas, declaraciones, biografías, autobiografías, etc., que le permiten identificar al personaje con el autor.

La imposibilidad de diferenciar una autoficción por sí misma incide en la inexistencia de rasgos pertinentes que permitan distinguirla de la novela y de la autobiografía, puesto que estas dos modalidades o géneros literarios cada vez comparten más técnicas narrativas y han llegado a ser, desde el punto de vista formal, indistinguibles. Como hemos venido explicando, la pertinencia de los rasgos propiamente autobiográficos no se encuentra en el texto, sino que son marcas extratextuales que tienen más que ver con la credibilidad que el lector concede al escrito que a la utilización de lugares, personajes y hechos históricos de los cuales pueden darnos fe un atlas, un diccionario enciclopédico, un callejero o un manual de historia universal. Ni 
siquiera la denominación o título de la obra sirven para separar la obra autobiográfica de la autoficción.

Dada la identidad narrativa entre autobiografía y novela, en que venimos insistiendo, hay que recurrir a factores externos para concederles unos límites propios que los contengan, y reconocer que en sus propias fronteras ha surgido un subgénero intermedio, un subconjunto narrativo autobiográfico que comparte características de ambos géneros a consecuencia de la intersección que se produce entre la realidad y la ficción a la hora de narrar(se). No obstante, es conveniente señalar que el yo en que se sustenta el género autobiográfico es una construcción artificial, cultural, y por tanto ficticia, que contamina y manipula en la narración la espontaneidad y sinceridad de los recuerdos para acomodarlos a una intención significativa. Esta artificiosidad que la autoficción ha puesto de relieve, a su vez, ha permitido cuestionar en gran medida el resto de modalidades autobiográficas, que gozaban de una ingenua permisividad por parte del lector confiado, hasta devolverlas a su condición de reconstrucciones estéticas, manipulaciones artísticas, independientemente del grado de verdad que quieran conferir a su texto.

Esta modalidad se configura, pues, como un ámbito intermedio que pone en comunicación dos realidades semejantes que los prejuicios estilísticos y canónicos habían delimitado como irreconciliables y casi antagónicos, pero que muestran su constante interacción. No hay que creer que este campo de intersección habilite el paso sólo en una dirección, es decir, como invasión de la novela en el campo autobiográfico, sino que cada vez más se tiende a novelar la narración autobiográfica con el fin de realzar su valor artístico, el carácter estético de la estructura que adopta un relato de vida.Cabe la posibilidad de que este entrecruzamiento, que empezó siendo un híbrido, acabe por acaparar toda posibilidad de escritura autobiográfica, supuesto que ha contemplado Alicia Molero (2000: 30) para avanzar las consecuencias que está acarreando esta ruptura de fronteras y el asentamiento de la autoficción como modalidad reconocida y estudiada con su propio perfil.

Esta hipótesis no es en absoluto descabellada, puesto que la evolución histórica del género autobiográfico viene a mostrar cómo los orígenes de esta modalidad se establecieron en una periferia vanguardista y revolucionaria que ha acabado reivindicando un ámbito particular para "constituirse en una provincia de la 
autobiografía con estatuto autonómico propio" (Alberca, 1999: 72) tras la provisionalidad como tierra de nadie inter-genérica que la caracterizó.

Si no existen en el plano formal diferencias entre la autobiografía como modalidad escriturística del yo y la novela autobiográfica (Villanueva, 1991: 112-113; 1993: 25) y las escasas barreras -indefinidas e indefinibles- que las separaban son constantemente transgredidas con cada vez mayor placer estético de lectores y autores, ¿qué puede diferenciar ambos géneros?

\section{LA MODALIDAD EPISTOLAR}

En la órbita de la autoficción, hay que plantearse si el uso o la imitación de las modalidades autobiográficas (en especial cartas y diarios) permite calificar a las obras que así lo hacen como autoficticias, y sobre todo hay que plantearse el motivo por el que se emplea una modalidad autobiográfica para facilitar el desarrollo de una narración ficticia. En el caso del empleo de la correspondencia epistolar como base y sustento para un argumento novelístico, hay que distinguir entre lo que Francisco López Estrada (1961: 25) denomina y define como ficción epistolar ("la obra literaria que finge por entero una relación entre personajes imaginados durante una correspondencia inventada") y aquellas obras en las que se incorporan textos epistolares al relato como una parte más de la novela.

La antigüedad del recurso epistolar en las obras ficticias se remonta, en la literatura europea, a Eneas Silvio Piccolomini, quien "usa la narración epistolar para su obra sobre los amores de Euríalo, franco, y Lucrecia, sienesa. Se titula la obra, Historia muy verdadera de un hecho que acaeció en 1434 ante el emperador Segismundo" (López Estrada, 1961: 133). Lo realmente interesante es comprobar cómo se comienzan a introducir en la literatura ficcional textos que imitan documentos de expresión personal que, por su propia naturaleza y su ámbito privado, no merecen un lugar destacado en la historia de la cultura y el pensamiento, pues pertenecen a seres anónimos e irrelevantes.

Sin embargo, la novela introduce estas formas de expresión en las que se comenzaba a formar y a forjar la subjetividad, de modo que el yo aún en formación comienza a filtrarse en los productos estéticos que demanda la nueva clase social burguesa. Inicialmente, esta irrupción se produce en un plano meramente formal, por lo 
que podemos suponer que el yo, como mito cultural burgués, tiene bastante de pose y de apariencia, al tiempo que su propia realidad proviene del entorno literario en que se muestra (Maravall, 1986: 298). Con vistas a un mejor entendimiento de cómo la ficcionalidad autobiográfica fue creándose y desarrollándose históricamente, hemos de incidir en la importancia que desempeñaron las cartas, por su versatilidad, por la carga de información narrativa y de perspectivismo que conllevan y por la cercanía con que trasmiten el mundo interior y externo del personaje.

Es preciso reparar en la vinculación que la carta tiene con el mundo amoroso, y por tanto con el ámbito de los sentimientos personales, subjetivos, que de otra manera no encontrarían cauces de expresión verosímiles, de donde deducimos que la carta fue incorporada al modelo narrativo occidental a fin de aportar credibilidad a los textos ficticios, en ese largo desarrollo que llevaría a la novela burguesa hasta su apogeo realista en el siglo XIX. En sus primeras fases de inserción en el mundo ficcional, la carta va a suponer una primera vía de escape del yo, de la subjetividad incipiente y del perspectivismo. Este triunfo, que abrirá la veta para futuras incursiones del yo en la ficción narrativa, incluida la novela picaresca, encuentra su explicación en el hecho de que en la carta (como sucederá en el diario) se perfila el fragmentarismo romántico (Arriaga Flórez, 2001: 62).

No es desdeñable, no obstante, el elemento subjetivo ligado a los sentimientos que también veíamos en los orígenes de esta incursión de lo personal como forma de expresión en la ficción novelística. Simultáneamente, la comunicación interpersonal se afianza en la clase burguesa, que precisa, dentro de la comunicación escrita de carácter privado, unos cánones o modelos que indiquen buenos modos, refinamiento educativo.

Sin duda alguna, será con el Romanticismo cuando la ficción epistolar alcance su apogeo, al unir dos características esenciales de la carta con el ideario del movimiento romántico: de una parte, su fragmentarismo perspectivista, expresión perfecta de un mundo desgarrado por la tragicidad interior, y de otra, la importancia que las sensaciones subjetivas y los sentimientos personales adquieren en la constitución del individuo. La máxima expresión de esta conjunción se muestra en la otra novela (de estructura epistolar) que marcará el éxito estético, ideológico y social del Romanticismo en Europa, Wherter.

Es obvio que a partir del Romanticismo nada va a ser igual, al triunfar plenamente el proyecto ilustrado de la Modernidad, con sus múltiples sugerencias y 
arrebatos. Es bien sabido que los ecos del Romanticismo siguen percibiéndose en nuestra conformación ideológica, estética y probablemente también sentimental (no sólo desde el punto de vista erótico o amoroso, sino también desde la rebeldía, el inconformismo intelectual, el ansia de libertad, etc.), por lo que en los últimos dos siglos su fuerza se ha ido desarrollando en sucesivos embates, que van desde las vanguardias estéticas hasta la Post-modernidad. Como manifestación post-romántica extrema, la Post-modernidad ha incidido en su visión desgarrada, fragmentaria, incoherente, contradictoria y pasional del individuo, creando un objeto estético lleno de sugerencias, que en el caso de la novela se convierte en un artefacto creado a través de la heterogeneidad y la superposición de modelos conocidos, cuya mezcla adquiere un nuevo significado.

El reciclaje, en este sentido, de la carta como expresión de la individualidad va más allá de su inserción como elemento aislado, para convertirse -como conjunto de relaciones establecidas- en el motor de la propia historia narrada. Del mismo modo que tradicionalmente se ha utilizado la carta para dar consistencia al argumento novelístico, el uso del diario para este fin es más reciente, se remonta al siglo XIX, aunque tiene idéntica finalidad, esto es, conseguir mayor verosimilitud al aportar la perspectiva íntima y subjetiva del narrador. A través del diario, por su carácter fragmentario, también se va a expresar y paralelamente a forjarse la subjetividad romántica.

La especificidad de la ficción diarística es que ésta no sólo ha ayudado a la conformación del intimismo y la subjetividad, sino que ha llegado a tener influencia en la práctica escritural de muchos lectores; es de sobra conocido el caso de la influencia que el Diario de Ana Frank ha tenido en muchos diaristas adolescentes (Lejeune, 1994: 426; Alberca, 2000: 24), y ya en la década de 1970 en adelante los libros de Michel Quoist (Diario de Daniel para los jóvenes y adolescentes, Diario de Ana María, para ellas), que tuvieron su traslación (que no traducción) en algunos libros del prolífico José Luis Martín Vigil, cuyos protagonistas escribían sus bellos sentimientos en los diarios que allí aparecían transcritos. Al tiempo que transmitían determinados valores y sentimientos, estas ficciones se convertían en ejemplos a imitar a la hora de escribir, con lo que se rizaba el bucle melancólico de la rebeldía romántica: el lector podría llegar a convertirse en su personaje y héroe literario, bastaba para ello con transcribir e idealizar las propias vivencias. Este fenómeno literario ha sido en gran parte causante de que se difundiese el mito del diario íntimo como una práctica exclusiva de adolescentes, mito 
que se remonta al siglo XIX ya que entonces se publicaban novelas con la forma de diarios, que Philippe Lejeune (1996: 72) ha estudiado para comprobar "en los diarios reales, el eco que había tenido una ficción pedagógica de éxito, el Journal de Marguerite, de Mlle. Monniot".

\section{CONTRATO DE LECTURA VARIABLE}

La cuestión principal que plantea la autoficción es saber de qué manera se establece la relación del lector con el texto, puesto que en los escritos autoficticios lo que nos encontramos es un diferente estatus ontológico de sus partes: unas pertenecen a la realidad autobiográfica, otras son metáforas de la vida del escritor, hay incluso fragmentos (distinguibles unas veces, indiscernibles otras) que son irreales y totalmente inventados. Esta diversidad ontológica que se ofrece, como un todo, en la autoficción, obliga a aplicar un sistema de interpretación variable o modulable, que afecta implícitamente al contrato de lectura, tal como veíamos que se establecía de forma unívoca en la autobiografía. Por ello, Lecarme y Lecarme-Tabone (1999: 267) plantean para el espacio autoficticio: "Il s'agira pour les écrivains de proposer des textes à regime narratif variable, à contrat de lecture modulable ou même parfaitement réversible". En este supuesto no sólo se encontrará el escritor, sino que el propio lector sabe que en el libro que lee los movimientos (como sucede con las apuestas bursátiles) son constantes, por lo que varía el valor y la función de cada parte del relato (en este caso, de cada biografema); al lector le quedará la posibilidad de acudir a otras fuentes (para-textuales) para contrastar la veracidad (o la falsedad) de la información suministrada.

Estamos, de este modo, ante un contrato de lectura variable o modulable que vincula a autor y lector en el planteamiento de un juego de sospechas e indagaciones que facilita la reconstrucción del texto a la medida de los intereses o convicciones previas del lector. Con esta modalidad de la autoficción, la autobiografía potencia el carácter autoconstructor del sujeto narrativo, que se define en la medida en que va narrándose, al tiempo que desvela el carácter lúdico en que consiste todo el arte moderno. El lector asume, ante la autoficción, el papel activo que ejerce el espectador en la estética contemporánea, que no se resigna a una condición de receptor pasivo. Con su juicio, su opinión y su entendimiento aplicado a las obras artísticas, el lector/espectador habrá de enjuiciar, no ya la sinceridad del autobiógrafo (que se da por 
supuesta), ni la veracidad de lo narrado, sino la función estética que cumple ese fragmento del relato en cuanto permite comprender en toda su magnitud la esencia de la vida que se le está relatando.

En la autoficción, por tanto, los conceptos de verdad o mentira no son operativos ni eficaces; lo realmente importante es la eficacia estética de la narración, estructurada con el fin de desvelar el secreto de una existencia, cuyos rasgos externos y datos aparente no pasan de meras anécdotas con las que el autor juega para dar más significado a un conflicto oculto que al lector compete descubrir e interpretar.

Si en la autobiografía destaca esa posibilidad de maquillar (que al fin y al cabo es enmascarar y deformar positiva o agradablemente) la realidad, en la autoficción esta hipótesis de embellecimiento que el autor ha podido aplicar sobre su persona se convierte en una obligación, aunque a condición de que el lector disponga en ese juego de comprensiones, búsquedas y complicidades de datos que le permitan deconstruir la figura que el autor traza de sí mismo y adaptarla a las creencias del lector. En la autoficción, la personalidad del alter ego o protagonista debe mostrar las fisuras que hagan posible, por sus contradicciones o dudas, de-construir al personaje y volverlo a montar según los criterios del lector, sus valores y sus creencias.

El personaje autoficticio, más allá de su verosimilitud y de su referencialidad con respecto al autor, es un ser fragmentado, desintegrado, que se presta a la reinterpretación mediante las múltiples re-lecturas que propicia el texto, ya que éste mismo es a su vez una interpretación codificada y metafórica de la vida del autor que en esa metáfora se re-presenta.

Se hace preciso, por consiguiente, revisar en sus términos el concepto de contractualidad que suscriben los agentes de un texto autobiográfico, esto es, autor y lector. Mientras que en la autobiografía dicho pacto, que colateralmente afecta al lector pero no lo implica, se suscribe formalmente entre el autor, el narrador y el personaje, cláusula fundamental para distinguir lo autobiográfico de lo novelesco, en la autoficción el pacto se suscribe fundamentalmente con el lector, con el texto como fedatario o intermediario (¿albacea testamentario, quizás?). Concebida como juego literario, la textualidad autoficticia asume los rasgos más innovadores del arte moderno, su sustancia intrínseca, a la que se ha referido Elena Trueba Mira (1999: 269) al aplicar los conceptos teóricos de la autoficción a la práctica concreta de la novela de Nuria Amat, La intimidad. 
A ese efecto lúdico que la auto(bio)ficción propone, al constituir al texto en una metáfora de la reconstrucción identitaria del sujeto por aquéllos que lo leen e interpretan desde fuera, con su multiplicidad y fragmentación resultante, se suma el hecho de que el nuevo paradigma estético de la Modernidad, aunque heredero de la referencialidad tradicional (la mimesis aristotélica), ha postulado un sistema cognitivo que no se basa en el concepto de exactitud y correspondencia del objeto artístico con la naturaleza, salto cualitativo que realizaron las vanguardias estéticas, propiciando de este modo la aparición del arte figurativo en pintura o la novela lírica en literatura. Si en el objeto estético ya no hemos de encontrar una referencia real, la autoficción se debate entre su condición de artefacto estético y su débito autobiográfico, que queda irresoluto y vacilante, al haber trascendido la necesidad representativa que el arte imponía antes de la revolución estética que supuso el Romanticismo en lo que fue su segundo embate, esto es, el Vanguardismo del primero cuarto del siglo XX.

En el plano literario, la ficcionalidad también ha superado las constricciones referenciales que llegan con su capacidad alegórica a la propia autobiografía, por lo que afrontar el entendimiento de la autoficción exige de la superación del canon o marco referencial. La vida en la autoficción se autogenera y reconstruye a sí misma con la sola ayuda del lector que dota de sentido aquello que el autor ha tendido como puentes para una nueva percepción de la realidad que está por hacer. Así, pues, el proyecto autoficticio epistemológicamente plantea nuevos retos, que se distribuyen por igual entre autor y lector.

Estamos, pues, ante una subversión, no de la realidad, sino del pacto autobiográfico, tal como han entendido ciertos autores esta realidad novedosa: la autoficción vendría a constituir un "contrapacto o pacto vacilante con el texto" (Trueba Mira, 1999: 269) al establecer un nuevo marco de relaciones entre el sujeto consigo mismo, con su sustancia textual y con las plasmaciones externas. En cierto modo, este nuevo escenario, que concuerda con el paradigma epistemológico de la Modernidad, tiene dos motivaciones básicas, las dos aludidas ya con anterioridad, pero que conviene recapitular llegados a este punto:

- De un lado, la autoficción es el resultado lógico de una síntesis que se ha ido produciendo paulatinamente en virtud de ese intercambio y préstamo de técnicas que han ido realizándose mutuamente autobiografía y novela, 
en cuanto manifestaciones artísticas de la Modernidad burguesa, y cuya síntesis se encuentra en esa búsqueda de un yo imposible, el yo del narrador que desde su posición personal en el mundo interpreta a éste.

- Por otra parte, el sujeto descubre la falsedad de su sustancia, lo que vendría a desmantelar progresivamente no sólo el mito del yo largamente creado por la burguesía y cuya descomposición se preludia en las manifestaciones artísticas de la vanguardia de entreguerras. Pere Gimferrer (1977: 26) concluía su estudio sobre el pintor alemán Max Ernst con esta destructiva visión de ese nuevo paradigma al que aboca la Post-modernidad estética, asomada a la vertiginosa contemplación de su propio abismo:

Denunciar que el mundo y nuestra identidad son ilusorios o susceptibles de desvanecerse, denunciar que no sabemos qué somos ni quiénes somos -punto de partida a la vez de la crítica radical, de la subversión profunda que Max Ernst opuso a la sociedad contemporánea, y de su lucidez poética de vidente-supone abrir las compuertas del pavor ante lo desconocido mental, que termina por ser [...] incluso lo desconocido físico, la negación de la realidad usualmente percibida. [...] Pero al fin vemos -o creemos ver- nuestro rostro: no está en este ámbito, no hay ni rostro ni ámbito, no tenemos rostro porque no tenemos identidad.

Ernst ha llegado al espacio donde nuestro rostro es el desvanecimiento de un rostro, donde nuestra identidad es la disolución de la identidad. En cuanto a las fronteras que separan (y comunican) lo autobiográfico de lo novelesco, la autoficción se convierte en el punto de encuentro, ambiguo y lábil, que confunde y potencia las diferencias y las similitudes entre ambas formas de expresión. En ese proceso de fusión fronteriza, la auto(bio)ficción representa la nueva concepción hipergenérica que ha hecho de la autobiografía un elemento esencial de la cultura contemporánea, un punto de inexcusable contradicción, en tanto su inexistencia como género literario tiende a tomar posesión de todos ellos. En la interpretación que hacemos de este fenómeno, se encuentra un hilo conductor que lleva desde la utilización de procedimientos narrativos similares hasta la ficcionalidad de la que la autobiografía se ha contagiado en su irresistible ocupación de los más diversos ámbitos de la vida cotidiana.

Esta mezcla de géneros, al tiempo que fomenta la ambigüedad supone un paso más para la constitución de lo autobiográfico como el hiper-género literario de la Post- 
modernidad, gracias a su perspectivismo, a su intrínseca fragmentariedad, a la paradójica condición de máscara identitaria que destruye toda relación de identidad con el yo referencial, etc. El carácter premeditadamente ambiguo que adoptan las autoficciones, que no reconocen abiertamente su condición de autobiografías, por lo que se presentan sinuosamente como novelas de base real, ha sido criticado por quienes como Ignacio Echevarría (2002: 36), desde su atalaya periodística en El País, contemplan con bastantes reticencias el creciente éxito cosechado por este tipo de narraciones indecisas y engañosas en cuanto a su adscripción genérica: "Por todas partes se percibe una creciente desinhibición de las relaciones entre realidad y ficción, que a menudo se sostienen en una calculada ambigüedad".

Lo que este crítico no ha llegado a comprender es que, a fuer de su amplia argumentación teórica, enlazada con los discursos desmitificadores y románticos de la Modernidad y la Post-modernidad, este tipo de obras cuenta con un respaldo mayoritario del público, que comprende y sigue perfectamente el juego planteado por el autor, más allá incluso de lo que piensa Lidia Masanet (1998: 54), quien circunscribe la aceptación de esta ambigüedad entre realidad y ficción a las narraciones de infancia. Pero la ambigüedad con la que juega conscientemente el autor (e incluso el editor, con la complicidad del crítico periodístico) es una condición sine quae non para la definición de los relatos autoficticios, "que se caracterizan por presentarse como novelas, es decir como ficción, y al mismo tiempo tienen una apariencia autobiográfica, ratificada por la identidad del autor, narrador y personaje" (Alberca Serrano, 1996a: 9).

Hemos apuntado, junto a la ambigüedad, la co-intencionalidad que precisa un texto autoficticio para ser reconocido como tal, puesto que el lector ha de asentir y consentir con su complicidad en el grado de identificación que existe entre el autor y su personaje en una obra de este tipo. Pero es evidente que al optar por la sugerencia y el misterio de la autoficción el escritor está significando una zona de sinuosidades y posibles re-interpretaciones que caen en manos del lector.

El origen de esta intencionalidad metafórica, misteriosa, ambigua, cargada de sugerencias y niveles significativos, se encuentra de nuevo en la utilización de la técnica novelesca de la condensación, que la autobiografía ha tenido que asumir para evitar el tedio que a menudo provoca la repetición de hechos triviales e intrascendentes que todo texto autobiográfico parece obligado a referir (nacimiento, familia, infancia, formación, primer recuerdo, etc.). 
La autoficción, por tanto, abre el campo a las interpretaciones simbólicas, al haber insertado la narración de la vida en un objeto estético, que a su vez concede la posibilidad al autor de manipular su propia existencia, lo cual proporciona una fuente de placer a quien utiliza lo que Ducio Demetrio (1999: 52) denomina el imaginario autobiográfico, que incluye la escritura personal y la ficcionalidad artística que reinterpreta en progresivas transformaciones al yo autorial. La única prevención que hemos de recoger, en este sentido, es que la intención autobiográfica, dentro del esquema autoficcional, no se marca unilateralmente, puesto que no se basa en una intepretación arbitraria del autor o del lector, sino en la coincidencia de ambas intenciones, a la hora de clasificar el texto, lo que aumenta su indefinición y su categoría genérica. La razón de esta indecisión o indefinibilidad respecto a la calificación de los textos como autoficticios proviene de la ausencia de marcas, esto es, la inexistencia de rasgos pertinentes, que indiquen que un biografema es real o ficticio, por lo que sólo la interpretación conjunta (autor-lector) de una obra hará del texto una autoficción operativa y eficaz.

En una narración de apariencia autobiográfica, la entidad ficticia del texto la equipara a una ficción, inventada totalmente, tanto por su carácter textual como por sus valores artísticos, así como por el uso que la novela tradicional puede hacer (y con frecuencia ha hecho) de una narración autobiográfica (en primera persona), motivo de confusión y de indiscernibilidad.

Uno puede rehacer su vida cambiando de ciudad o transformando los hábitos de vida, conociendo a nuevas personas o abandonando todo lo que ha marcado su vida en el pasado, pero la literatura permite rehacer la propia vida y la de los demás, no sólo hacia el futuro, sino también en lo que atañe al recuerdo. En el discurso de recepción del premio Nobel de Literatura en la Academia Sueca, el 7 de diciembre de 1998, José Saramago (1999: 14) explicó de forma magistral cómo a través de la ficción literaria había podido recuperar la memoria que tenía de sus abuelos:

Tuve conciencia de que estaba transformando las personas comunes que ellos habían sido en personajes literarios y que ésa era, probablemente, la manera de no olvidarlos, dibujando y volviendo a dibujar sus rostros con el lápiz siempre cambiante del recuerdo, coloreando e iluminando la monotonía de una cotidianidad opaca y sin horizontes como quien va recreando, por encima del inestable mapa de la memoria, la irrealidad sobrenatural del país en que decidió pasar a vivir. 
En su lucha contra el olvido, la memoria autobiográfica se convierte ella misma en una ficción, por lo que para un análisis textual no pueden existir criterios que distingan la realidad de la invención; en cuanto producto narrativo, "todo texto autobiográfico es por sí mismo una historia ficticia. Toda autobiografía es una forma de ficción" (Tortosa Garrigós, 1998: 432). De hecho, si se pretende acceder a los territorios del pasado, como veíamos en la evocación de José Saramago, la única posibilidad que se ofrece es la de ficcionalizar, esto es, fingir, imaginar y crear de nuevo aquel mundo que habitamos y que no volverá a ser.

La literatura se convierte en una llave para el acceso al tiempo clausurado por haberse convertido en pasado, gracias a su capacidad narrativa, que facilita la recomposición imaginaria del decurso lineal de la historia; este re-hacerse $\mathrm{o}$ reconstituirse no sería posible sin la actuación conjunta de la memoria y la imaginación, puestoo que en la autoficción el elemento narrativo tiene como premisa la posibilidad de inventar y mentir, por lo que la autobiografía puede refugiarse en la novela para hacer más eficaz esa reconstrucción del yo que ha desaparecido, de modo que puede usar los recursos de la novela, como venimos insistiendo, del mismo modo que la novela imita sin mayores problemas los procedimientos y ténicas de autoprospección empleados tradicionalmente por la autobiografía, haciendo que sea formalmente indistinguible una autobiografía de una novela.

Se puede contemplar, por tanto, la naturaleza híbrida de la autoficción como una intrusión de la fantasía en la autobiografía, o bien como una inclusión arrolladora del realismo en la ficción literaria, puesto que en cualquiera de los dos casos nos encontramos en un plano de irresponsabilidad, esto es: ni la ficcionalización de la propia vida desmiente el carácter autobiográfico que la narración autoficticia ostenta, ni al contrario "a veracidade de certos factos nâo desvirtua a natureza ficcional das obras", como señala Martins (1994: 64) refiriéndose a la obra del portugués Aquilino Ribeiro, A Vida Sinuosa, que claramente apunta a una narración (auto)biográfica, aunque incluye elementos ficticios que dieron lugar a la confusión de lectores que reclamaron daños y perjuicios que sólo se habían cometido en la narración, advirtiendo de los peligros que provoca una lectura unívoca que no entienda el ludismo implícito en todo artefacto estético.

Más allá de las situaciones problemáticas a que pueda dar lugar la autoficción, que por ello reclama la impunidad de lo irreal para expresar con mayor libertad la 
propia vida del autor, la correspondencia con otras vidas y su derecho a exponer el punto de vista que le compete, hay que indicar que esta coexistencia de la premeditada ficción con el relato coincidente con la vida del autor ha propiciado un nuevo escenario, lo que Masanet (1998: 8) denomina "los nuevos parámetros vertebradores de los textos autobiográficos", sobre todo porque este artificio ha puesto en evidencia el carácter retórico de la autobiografía en general.

Si damos por supuesto que cada quien es dueño de su vida, no sólo para vivirla (incluso para morirla), sino también para contarla, para extraer de ellas los aspectos que considere más oportunos, es lógico que en el relato de esa vida se introduzca un elemento de ficcionalización que la embellece, mitifica y hace más atractiva. Así lo constata Francesc Espinet (1991: 66), quien resume así el trabajo de investigación realizado por sus alumnos al recoger testimonios de vida o autobiofonías de personas mayores en el área catalana:

Esta construcción en ocasiones llega a literaturizar en exceso el relato (hasta el extremo de que algún autor le da el nombre de novela), acudiendo a diversos expedientes, los más comunes de los cuales son una estilización abarrocada de poco vuelo, o dar al relato el sentido de aventura.

En gran número de ocasiones, los relatos de vida que se hacen en la edad provecta con carácter pseudo-literario (por sus exageraciones retóricas y el afectado y rancio estilo) aceptan la ficcionalidad implícita del proyecto. Aparte de esa tendencia a sublimar e idealizar la propia vida, antes de proceder a ese inventario testamentario que en diversos grados cumple todo texto autobiográfico, hay que resaltar dos factores que han permitido la consolidación de la autoficción como género de enorme receptividad en el público lector de finales del siglo XX y principios del XXI:

- De una parte, nos hallamos ante un tipo de relato que no exige de una especial capacitación para el que lo practica, reportando el gran placer de satisfacer al propio ego, su afán de notoriedad y/o el mero gusto de narrar y hablar de uno mismo.

- Por otra parte, en la autoficción se pone de manifiesto el avance implacable de la autobiografía como hiper-género que se filtra a través de las más diversas manifestaciones estéticas de la contemporaneidad, constituido en las 
últimas décadas en la persecución de un sentido en la búsqueda identitaria que se produce en el arte.

Es preciso insistir en la libertad que la autoficción presta al escritor, no sólo por esa imponidad que en nombre de la estética libre reivindica el artista moderno, sino porque ella le amplía las posibilidades de narración y sus márgenes. Esta virtualidad de vivir las diversas personas que lo habitan (¿las personas del verbo?, nos preguntaríamos recordando a Jaime Gil de Biedma), se complementa con la vampirización de vidas ajenas.

A través de la autoficción, además de encontrar la virtualidad con que la literatura puede acceder al cumplimiento de los deseos y las aspiraciones incumplidas, se renueva la percepción de que la novela surge de una vivencia y se debe a una realidad previa que ha sido depurada y ampliada para hacerla comprensible, tanto al lector como al propio escritor que mediante la ficción accede a partes secretas, misteriosas, de su existencia.

En la autoficción no se halla en juego el predominio de la realidad o la imaginación, como si ambos límites fueran infranqueables e irreconciliables; por el contrario, los textos autoficticios muestran que existe una interpenetrabilidad entre ambos, que la realidad es otra forma de la imaginación, tal y como es procesada y reconstruida por la mente humana, y que la imaginación forma parte de la realidad, está incluida en ella.

En los textos autoficticios, lo más real puede responder a una reconstrucción imaginaria, y lo que aparenta mayor seguridad (la voz narrativa, por ejemplo) ser inconsistente y ficticio, un reflejo o un símbolo. La lógica plurimodal ha aceptado como posible la coexistencia de dos predicados o afirmaciones contradictorias entre sí respecto de aquello que se predica, por lo que la epistemología contemporánea se va acercando a una libertad imaginativa y constructiva del mundo real que nos rodea; Xavier Pla Barbero (1997: 29) significa que esta situación ya se encuentra en algunos textos autoficticios, que abren la multiplicidad de dimensiones existentes entre la realidad y la ficción, entre lo posible y lo necesario, al referirse a la obra autoficticia de Pla.

La mezcla entre imaginación y probabilidad o realidad se produce en la tradición cultural de Occidente dentro del género novelístico, del que la autobiografía y con ella 
la autoficción en mayores proporciones recoge esa virtualidad plurisignificativa y simbólica de los personajes y de sus situaciones, al establecer nuevos marcos de relación conceptual con el mundo referencial que pretende reproducir.

De esa mutua interdependencia propiciada por la literatura se aproxima el escritor a la verdad, que en ningún caso puede tener una interpretación unívoca e irrevocable, por lo que el texto autoficticio se aprovechará del "poder de la ficción como excelente instrumento de conocimiento y vía de acercamiento a la realidad" (Cañedo, 2000: 563), una vez se sabe que el pasado que se pretende reconstruir es un símbolo, del mismo modo que el yo o la vida, y que sólo a través de las metáforas se puede producir el conocimiento, ya que gracias a ellas reconstruimos y elaboramos la realidad que nos afecta. La autoficción se plantea, pues, como un proceso gnoseológico cuyo fin es comprender y asimilar, recuperar el dominio sobre nosotros mismos, en cuanto lectores, reproduciendo con ello el afán del escritor que se textualiza para darse a conocer, para entenderse y explicarse a sí mismo, para lo cual tiene que explicitarse y recuperar su condición de símbolo al que sólo otros símbolos trasladan y traducen.

Se ratifica así cuanto decíamos de la reducción que el escritor hace de sí mismo al intentar amplificarse y magnificarse convirtiéndose en texto, asimilándose a la ficcionalidad textual, por lo que "toda biografía, en última instancia, no es más que un acto especulativo que no ofrece mayores certidumbres que la ficción o el análisis del texto en sí mismo" (Montes Huidobro, 2001: 16), máxime en una época de extrema permeabilidad entre conceptos como realidad, imaginación, ficción, etc. El perspectivismo implícito en cada interpretación que de la realidad efectúa cada persona al narrar un suceso de su vida se halla inserto en dos coordenadas: la de la significación que atribuye al transcurrir de su existencia el propio autor, que le concede una importancia o un valor concreto dentro de la totalidad del proyecto autobiográfico y vital a dicho acontecimiento, que una vez pasado a la textualidad podríamos considerar un biografema, y la otra coordenada es la concreta posición que adoptó como participante en el mismo, que hace que su versión pueda contrastarse por sus diferencias con lo que otros testigos han contado del mismo.

En alguna medida, toda novela es el resultado de una experiencia personal; la autoficción hace coincidir la narración de esa experiencia con el punto de vista desde el que fue vivida y observada, pero la presencia de elementos autobiográficos no empece la utilización de datos imaginados. Lo que busca el novelista con la inserción de 
elementos imaginarios o fantasiosos en el relato de su vida es ampliar el marco referencial de su experiencia, concederle un valor simbólico y metafórico que transfigure su propia vida. La ficción, en este caso, sirve para enriquecer al sujeto narrativo, cargándolo de significaciones que ayuden a entender y conocer mejor su entorno.

Aunque no es obligatorio el uso de la primera persona de singular en las autoficciones, al igual que ocurre con las autobiografías, sí que nos encontramos ante la opción del escritor de cualquier mecanismo de identificación que le permita darse a conocer como protagonista de la historia que narra, aunque como advierten Lecarme y Lecarme-Tabone (1999: 269) no debe confundirse el uso de la persona gramatical con la modalidad o subgénero literario. Esta cuestión nos lleva a plantear si, como defiende Manuel Alberca (1999: 65), las autoficciones se caracterizan porque el nombre propio del protagonista coincide con el del autor o si no es un requisito imprescindible; hay dos motivos por los que consideramos que dicho requisito no es de obligado cumplimiento, a saber:

- En primer lugar, porque el autor está en su derecho de emplear un pseudónimo con el que protegerse o expresarse, usando por tanto su personaje un nombre que lo identifique, que le sirva para crear vínculos y relaciones con esa denominación arbitraria que ha elegido para su criatura ficticia, pero que, no lo olvidemos, dicho nombre es tan arbitrario como el suyo oficial, el que figura en los registros y documentos.

- Por otra parte, dado el carácter ficticio o arbitrario del nombre, que actúa como máscara social y también literaria, lo importante es que el texto autonovelesco revele y descubra la ficcionalidad del ser que se narra a sí mismo, y para ello los procedimientos son diversos y cualquiera de ellos puede ser válido, pues todos llevarán a esa sinuosa y ambigua identificación a la que la autoficción quiere conducir, puesto que lo que se produce es una "identificación en el plano de la enunciación y una semejanza en el plano del enunciado" (Tortosa Garrigós, 2001: 57).

El propio Alberca (1999: 66) se ha llegado a referir a algunos procedimientos de identificación que emplea el autor autoficticio para que en su texto se pueda producir el 
pacto ambiguo que caracteriza a la auto(bio)ficción, incluso cuando en los casos más extremos desposee del nombre al protagonista en el que refracta sus vivencias:

Cuando el anonimato del narrador-protagonista es riguroso, la atribución a éste en la novela de obras o libros conocidos del autor, o de evidentes o reconocibles referencias biográficas del mismo, suple la identidad nominal exigida por el género y todo me induce a pensar que se cumplen las condiciones y efectos de dicho pacto.

Al traspasar la vida a un texto, toda autobiografía acaba convirtiéndose en una ficción, sobre todo porque inventa a un personaje, el narrador que se autoconstruye y se auto-inventa; la autoficción ha puesto al descubierto el carácter ficcional del yo autobiográfico, su inexistencia real fuera de los márgenes y máscaras que le presta la literatura. En la novela autobiográfica, no sólo se pueden adjuntar elementos fantasiosos o imaginados, sino que la propia personalidad del escritor es producto de la imaginación.

De esta manera, la autoficción puede interpretarse como la exageración imaginaria de los rasgos ficticios que presentan todas las formas autobiográficas, con su tendencia a la creación de un personaje, con la incorporación a éste de rasgos idealizados, ejemplarizantes, coherentes, que en gran medida provienen de la perspectiva desde la que es reconstruido. Estamos por afirmar, incluso, que los efectos culturales que la literatura ha tenido sobre los ciudadanos y lectores occidentales hacen que todos nosotros nos creamos protagonistas de una novela, contagiados como estamos por los sentimientos de los que en los textos literarios se habla. La creación de un proyecto autobiográfico propio, por el que los textos autobiográficos vienen solamente a desvelar los motivos que han impulsado, real o imaginariamente, la vida de un individuo concreto, puede deberse al efecto de la ficcionalidad sobre la vida de las gentes, que asumen así el carácter narrativo de los sucesos que viven como si de moldes novelísticos se tratase.

En esta interacción entre ficcionalidad $y$ vivencia se ha instalado la auto(bio)ficción como un modelo creativo que acerca aún más la expresión artística a la cotidianidad de seres que están hartos de contemplarse a sí mismos como espectadores pasivos $^{2}$ en un mundo donde todo se les da hecho, ya que las decisiones políticas y

2 “Quizá sea [é]sa la razón por la que un gran número de novelas recurre a la primera persona como un instrumento de persuasión y a historias que han de competir con todas aquellas que los lectores 
económicas les vienen dadas desde arriba, las noticias que leen o escuchan provienen de empresas que las han filtrado previamente, los productos que consume son creaciones de la publicidad que conecta a dichos productos la esperanza ficticia del bienestar o la felicidad. En una sociedad que ha accedido a un mundo de información globalizada, no es de extrañar que cada quien, en respuesta a una crisis de crecimiento que amenaza con romper los signos de individualidad y de identidad cultural, espere de la ficción que le devuelva su espacio esencial de protagonismo, su capacidad de expresión y de entendimiento.

La trampa que supone la ficcionalización del sujeto no es sino una huida de la anomia social que en distintas fases y grados ha venido afectando al individuo desde los orígenes de la creación y potenciación del yo moderno, desgajado de la sociedad estamental en que había vivido para dar paso a la primera fractura de la Modernidad, el Renacimiento, y más adelante con su disolución en la vida urbana y en el engranaje industrial que anula sus distintivos mientras predica esos mismos valores que en la práctica se desdeñan, para llegar a la situación de finales del siglo $\mathrm{XX}$ en que el ser humano se siente un objeto estadístico, destinado a consumir, a votar y a recibir información. Tal vez estos datos sociológicos también nos permitan interpretar por qué la autoficción se ha consolidado como una tendencia cada vez más pujante entre los escritores actuales, si tenemos en cuenta que este modelo narrativo responde a la conciencia de un desgarramiento, también de una exclusión, por lo que el sujeto se reficcionaliza para escapar de la alienación que le supone ser considerado como un número.

\section{REFERENCIAS BIBLIOGRÁFICAS}

Alberca Serrano, M. (1996a). "El pacto ambiguo". Boletín de la Unidad de Estudios Biográficos, 1, 9-19.

están habituados a encontrarse cada día en los periódicos o en los televisores, historias de las que tienen conocimiento a las pocas horas de acontecidas, [aun] cuando hayan ocurrido en el último rincón de la tierra" (Trapiello, 1998: 155). 
- (1996b). “¿Es literario el género autobiográfico? Tres ejemplos actuales”. En Mundos de ficción (Actas del VI Congreso Internacional de A.E.S.), José María Pozuelo Yvancos y Francisco Vicente Gómez (eds.), 175-183. Murcia: Universidad de Murcia.

- (1999). "En las fronteras de la autobiografía". En Manuela Ledesma Pedraz (ed.), Escritura autobiográfica y géneros literarios, 53-75. Jaén: Universidad de Jaén. - (2000). La escritura invisible. Testimonios sobre el diario íntimo. Oiartzun: Sendoa. Arriaga Flórez, M. (2001). Mi amor, mi juez. Alteridad autobiográfica femenina. Barcelona: Anthropos.

CATELLi, N. (1986). El espacio autobiográfico. Barcelona: Lumen.

Demetrio, D. (1999). Escribirse. La autobiografía como curación de uno mismo. Barcelona: Paidós.

EAKIN, P. J. (1994). "Introducción”. En Philippe Lejeune, El pacto autobiográfico, 946. Madrid: Megazul-Endymion.

EChevarRía, I. (2002). "Una relación promiscua”. El País, 12 de enero, 36.

ESPINET I BURUNAT, F. (1991). "Cataluña 1888-1936 a través de las autobiografías". Anthropos 125, 65-70.

FranZINA, E. (1992). "Autobiografías y diarios en la emigración. Experiencia y memoria en los escritos autobiográficos de emigrantes e inmigrados en América entre los siglos XIX y XX”. Historia social, 14, 121-142.

GiMfERRER, P. (1977). Max Ernst o la disolución de la identidad. Barcelona: Polígrafa. Giné, M. y Sala-Valldaura, J. M. (1998). "Nota preliminar". En Marta Giné y J. M. Sala-Valldaura (eds.), L'escriptura i la vida, 9-10. Lleida: Pagès editors / Universitat de Lleida.

Lecarme, J., Lecarme-Tabone, É. (1999). L'autobiographie. Paris: Armand Collin.

Ledesma Pedraz, M. (1999). "Cuestiones preliminares sobre el género autobiográfico y presentación”. En Manuela Ledesma Pedraz (ed.), Escritura autobiográfica y géneros literarios, 9-20. Jaén: Universidad de Jaén.

LeJeune, Ph. (1994). El pacto autobiográfico y otros estudios. Madrid: MegazulEndymion.

— (1996). "La práctica del diario personal: una investigación (1986-1996)". Revista de Occidente, 182-183, 55-75. 
LÓPEz EstradA, F. (1961). “Introducción general”. En Antología de epístolas. Cartas selectas de los más famosos autores de la historia universal, 3-161. Barcelona: Labor.

Maravall, J. A. (1986). La literatura picaresca desde la historia social. Madrid: Taurus.

MARTinS, S. (1994). “Autobiografia e ficçao em Obras de Aquilino Ribeiro". Românica. Revista de Literatura, 3, 163-177. Universidad de Lisboa.

MASANET, L. (1998). La autobiografía femenina española contemporánea. Madrid: Fundamentos.

MAY, G. (1982). La autobiografía. México: Fondo de Cultura Económica.

Molero de la Iglesia, A. (2000). La autoficción en España. Jorge Semprún, Carlos Barral, Luis Goytisolo, Enriqueta Antolín y Antonio Muñoz Molina. Berna: Peter Lang.

MolinO, J. (1991). “Interpretar la autobiografía”. En Antonio Laza Pozuelo (ed.), La autobiografía en lengua española en el siglo veinte, 107-137. Lausanne: Hispánica Helvética.

Montes Huidobro, M. (2001). La distorsión sexo-lingüística en Ángel Ganivet. Granada: Universidad de Granada / Diputación Provincial de Granada.

NAVAJAS, G. (1987). Teoría y práctica de la novela española posmoderna. Barcelona: Edicions del Mall.

Pla BARBERO, X. (1997). “Josep Pla: biografía, autobiografía, autoficción”. Cuadernos Hispanoamericanos, 567, 21-29.

SARAMAgO, J. (1999). "De cómo el personaje fue maestro y el autor su aprendiz". Casa de las Américas, 24, 13-20.

TORTOSA GARRIGÓs, V. (1998). La construcción del individualismo en la literatura de fin de siglo. Historia y autobiografía. Tesis doctoral, Universidad de Valencia. (En www.cervantesvirtual.com).

- (2001). Escrituras ensimismadas. La autobiografía literaria en la democracia española. Alicante: Universidad de Alicante.

Trapiello, A. (1998). El escritor de diarios. Historia de un desplazamiento. Barcelona: Península.

Trueba MirA, V. (1999). "La escritura de la intimidad (una novela de Nuria Amat). Notas y Estudios Filológicos, 14, 267-279. 
VillanueVA, D. (1991). "Para una pragmática de la autobiografía", en El polen de las ideas, 95-114. Barcelona: PPU.

— (1993). "Realidad y ficción: la paradoja de la autobiografía". En José Romera (ed.), Escritura autobiográfica. Actas del II Seminario Internacional del Instituto de Semiótica Literaria y Teatral, 15-31. Madrid: Visor. 